\title{
Association between CETP Taq1B and LIPC -514C/ $T$ polymorphisms with the serum lipid levels in a group of Tehran's population: a cross sectional study
}

\author{
Mohammad Ali Kashani Farid ${ }^{1}$, Fereidoun Azizi ${ }^{2}$, Mehdi Hedayati ${ }^{2}$, Maryam S Daneshpour ${ }^{3}$, \\ Ahmad Reza Shamshiri ${ }^{4}$, Fereydoun Siassi ${ }^{*}$
}

\begin{abstract}
Background: Low level of high density lipoprotein cholesterol (HDL-C) has high prevalence in the Tehran Lipid and Glucose Study (TLGS) cohort. About 50\% of the inter-individual variation in serum HDL-C levels is genetically determined. Polymorphisms in cholesteryl ester transfer protein (CETP) and hepatic lipase (LIPC) genes have been found to be associated with the metabolism and serum concentration of the HDL-C.

Objectives: To determine the association between Taq1B polymorphism in CETP gene and -514C/T polymorphism in LIPC gene with serum lipid levels and lipid peroxidation in a subgroup of the TLGS population.

Results: Serum HDL-C level had significant association with CETP Taq1B polymorphism and B2B2 subjects had the highest HDL-C levels compared to B2B1 and B1B1 genotypes (37.9 vs. 36.9 and $35.3 \mathrm{mg} / \mathrm{dl}$, respectively; $P=0.01$ ). However, carriers of "B1" allele, in comparison to the non carriers (B2B2), had significantly lower levels of TC (200.1 vs. $215.2 \mathrm{mg} / \mathrm{dl} ; P=0.005)$, HDL-C (35.8 vs. $37.9 \mathrm{mg} / \mathrm{dl} ; P=0.009)$ and malondialdehyde MDA (4.5 vs. $5.0 \mathrm{nmol} / \mathrm{mL}$; $P=0.031$ ). Carriers of the "T" allele in $-514 C / T$ polymorphism in LIPC gene had higher means of HDL-C than non carriers ( 37.7 vs. $35.7 \mathrm{mg} / \mathrm{dl}, P=0.04$ ). No other association was found between $-514 \mathrm{C} / \mathrm{T}$ polymorphism and any other serum lipids or MDA level.
\end{abstract}

Conclusion: This study demonstrates the association between Taq1B and $-514 \mathrm{C} / \mathrm{T}$ polymorphisms in the CETP and LIPC genes with the serum HDL-C levels.

\section{Introduction}

Coronary artery disease (CAD) and stroke are the leading causes of morbidity, mortality and disability in industrialized countries, and the prevalence of these diseases is increasing rapidly in developing countries[1].

Convincing clinical evidence has shown an association between the incidence of CAD and low levels of HDL-C $[2,3]$. Epidemiological studies have shown a $2-3 \%$ increase in CAD risk for each $1 \mathrm{mg} / \mathrm{dl}$ decrease in HDL-C level[4]. Angiographic and ultrasonographic data also indicate that low levels of HDL-C are associated

\footnotetext{
* Correspondence: siassif@tums.ac.ir

'Department of Nutrition and Biochemistry, School of Public Health, Tehran University of Medical Sciences, Tehran, I.R.Iran

Full list of author information is available at the end of the article
}

with the risk and severity of CAD, carotid disease, and postangioplasty restenosis $[5,6]$.

Fat type and its percentage in diet, smoking, alcohol, body mass index (BMI) and physical activity [7] all have a role in determining individual HDL-C levels; however, family studies suggest that about $50 \%$ of the inter-individual variation in serum $\mathrm{HDL}-\mathrm{C}$ levels is genetically determined $[8,9]$. Polymorphisms in cholesteryl ester transfer protein (CETP) $[9,10]$ and hepatic lipase (LIPC) $[11,12]$ genes have been found to be associated with the variations in the $\mathrm{HDL}-\mathrm{C}$ concentration.

Cholesteryl Ester Transfer Protein (CETP) is a hydrophobic glycoprotein that circulates in plasma bound mainly to HDL-C[13]. It promotes the redistribution of cholesteryl esters, triglycerides, and, to a lesser extent, 
phospholipids between plasma lipoproteins[14]. Recent genome-wide association studies have reported that CETP genotypes are associated with HDL-C levels more strongly than any other loci across the genome $[9,10]$.

The most studied CETP restriction fragment length polymorphism (RFLP) has been the TaqIB (Rs708272) in the 277th nucleotide of the first CETP intron [15]. The less common "B2" allele (absence of the TaqIB restriction site) has been associated with increased HDL-C levels and decreased CETP activity and levels[16].

Hepatic lipase (HL) is a lipolytic enzyme that plays a role in triglyceride hydrolysis, phospholipid lipolysis, LDL-C remodeling and HDL-C metabolism[17]. HL promotes the conversion of buoyant HDL2-C particles to small and dense HDL3-C particles by remodeling triglycerides and phospholipids[18]. This process may induce cholesterol ester efflux from peripheral tissues to the lipase containing tissues $[19,20]$. Therefore, HL is not only a determinant of HDL-C cholesterol levels but also may be an important element in reverse cholesterol transport [21].

A common " $C$ " to " $\mathrm{T}$ " substitution has been described in nucleotide -514 in the promoter region of the hepatic lipase gene. "T", the less common allele of the $-514 \mathrm{C} / \mathrm{T}$ polymorphism ( $r$ 1800588), is associated with decreased plasma $\mathrm{HL}$ activity and increased HDL-C concentrations in many populations [22-25]; some other studies, however, have failed to demonstrate such an association [26-29].

Iran is considered a nation in nutritional, economic and demographic transition with a growing number of cases with cardiovascular disease and metabolic syndrome [30,31]. The Tehran Lipid and Glucose Study (TLGS) is a large cohort study that explores the risk factors for non-communicable diseases among Tehran's population [30]. Result of the first phase of the TLGS has shown HDL-C levels below $35 \mathrm{mg} / \mathrm{L}$ in $32 \%$ of adult subjects [30]. In comparison, only $16-18 \%$ of men and $3-6 \%$ of women in the US have HDL-C levels below 35 $\mathrm{mg} / \mathrm{L}[32,33]$. The average HDL-C level of the TLGS community, was also found to be lower than the populations in the US [34], Europe[35], and Turkey [36].

The objectives of the present study were to: (a) determine the frequency of CETP Taq1B and LIPC $-514 \mathrm{C} / \mathrm{T}$ polymorphisms in a subgroup of the TLGS cohort; (b) investigate the possible effect of genetic polymorphism at these loci on the low HDL-C serum levels in this population; and (c) explore the association between these single nucleotide polymorphisms (SNPs) and lipid peroxidation.

\section{Materials and methods}

This cross-sectional study was carried out in a subpopulation of the TLGS cohort. In brief, TLGS is a large scale community based study with a population of 15,005 people that has been launched since 1999 in the $13^{\text {th }}$ district of Tehran, the capital of Iran [30]. More details about the rationales and design of the TLGS have been published elsewhere [37].

By random sampling, 203 men and 252 women aged 30 to 88 , who were not on any lipid-lowering treatment, were recruited for this study. The sex ratio of the subjects was similar to the TLGS population. The Medical Ethics Committee of the Research Institute for Endocrine Sciences at Shahid Beheshti University of Medical Science has reviewed and approved the protocol of the study. Besides, an informed written consent was obtained from each subject. All participants were interviewed and clinically examined by a qualified physician. In each subject anthropometric variables such as weight, height, waist and hip circumference, BMI and blood pressure were also measured. More detail about the methods used for these measurements has been previously reported $[30,37]$. SPSS program was used for data entry and analysis. A fasting blood sample was collected for each participant.

\section{Laboratory measurements Blood Sampling}

After an overnight fast $8 \mathrm{~mL}$ blood sample was collected. The serum was isolated by centrifugation (3000 $\mathrm{rpm}, 10 \mathrm{~min}, 4^{\circ} \mathrm{C}$ ) and 4 aliquots of $1 \mathrm{~mL}$ were frozen at $-80^{\circ} \mathrm{C}$ for measurement of lipids and MDA level.

\section{Lipids}

Serum concentrations of TC and TG were determined through enzymatic colorimetric assay (TC \& TG Kit, Pars Azmoun, Iran). HDL-C was also measured by precipitating-enzymatic colorimetric assay after precipitation of the apo B-containing lipoproteins with phosphotungistic acid (Pars Azmon Kits, Iran). LDL-C was calculated by the Friedewald formula [38]. LDL-C calculation was ignored if $\mathrm{TG}$ concentration was $>400 \mathrm{mg} / \mathrm{dl}$. Assay performance was monitored with an interval of every 20 tests using the lipid control serum, Precinorm [normal range] and Precipath [pathologic range] wherever applicable (Boehringer Mannheim, Germany; cat. no. 1446070 for Precinorm and 171778 for Precipath). Lipid standard (C.f.a.s, Boehringer Mannheim, Germany; cat. no. 759350) was used to calibrate the Selectra 2 auto-analyzer on all days of laboratory analysis. All samples were analyzed when internal quality controls were in the acceptable range. Inter- and intraassay coefficients of variation were 2 and $1.1 \%$ for TC and 2.1 and $1.3 \%$ for TGs, respectively.

Concentration of serum MDA - as a marker for lipid peroxidation - was measured by its reactivity with thiobarbituric acid[39] (Cayman's TBARS Assay Kit - USA Catalogue No. 10009055). 


\section{DNA Extraction}

Blood leukocytes purification and DNA extraction from it was carried out as described by Truett, et al.[40]. The concentration and purity of the extracted DNA were determined by spectrometry. DNA samples were then stored in aliquot at " $-20^{\circ} \mathrm{C}$ " for future analysis.

\section{CETP Genotyping}

A fragment of $535 \mathrm{bp}$ in intron 1 of the CETP gene was amplified by polymerase chain reaction (PCR) in a DNA Thermal Cycler (Hybaid co. England) as described by Ordovas et al [41] with the use of oligonucleotide primers (forward 5'-CACTAGCCCAGAGAGAGGAGTGCC-3', Reverse: 5'-CTGAGCCCAGCCGCACACTAAC-3'). The PCR was performed by using $100 \mathrm{ng}$ genomic DNA in a final volume of $50 \mathrm{~mL}$ containing $40 \mathrm{pmol}$ of each oligonucleotide, $0.2 \mathrm{mmol} / \mathrm{L}$ dNTPs, $1.5 \mathrm{mmol} / \mathrm{L} \mathrm{MgCl} 2$, $10 \mathrm{mmol} / \mathrm{L}$ Tris, $\mathrm{pH} 8.4$, and $0.25 \mathrm{U}$ of Taq polymerase. (Fermentas Co. Canada), $0.75 \mathrm{mmol} / \mathrm{L} \mathrm{MgCl} 2$ and $10 \mathrm{mmol} / \mathrm{L}$ Tris, $\mathrm{pH}$ 8.4. After initial denaturation at $96^{\circ} \mathrm{C}$ for $5 \mathrm{~min}$, PCR was carried out for 35 cycles, each one comprised of denaturation at $95^{\circ} \mathrm{C}$ for 45 seconds, annealing at $65^{\circ} \mathrm{C}$ for $1 \mathrm{~min}$, and extension at $72^{\circ} \mathrm{C}$ for $1 \mathrm{~min}$, with a final extension time of $5 \mathrm{~min}$ at $72^{\circ} \mathrm{C}$. The PCR products were subjected to restriction enzyme analysis by digestion with TaqI restriction endonucleases (Fermentase Canada) at $65^{\circ} \mathrm{C}$ for $2 \mathrm{~h}$. The fragments were separated by electrophoresis on a $1.5 \%$ agarose gel. After electrophoresis, the gel was treated with ethidium bromide for 20 min, and DNA fragments were visualized by UV illumination. The resulting fragments were 174 and $361 \mathrm{bp}$ for the "B1" allele and $535 \mathrm{bp}$ for the uncut "B2" allele.

\section{LIPC Genotype}

Hepatic lipase genotyping was performed as described by Guerra et al [11]. A 285-bp sequence of the LIPC gene was amplified by polymerase chain reaction (PCR) by using oligonucleotide primers 5'-TCTAGGATCACCTCTCAATGGGTCA-3' and 5'-GGTGGCTT CCACGTGG-CTGCCTAAG-3'. DNA templates were denatured at $95^{\circ} \mathrm{C}$ for $3 \mathrm{~min}$, and then each PCR was subjected to 35 cycles, each consisting of 30 seconds of denaturation at $95^{\circ} \mathrm{C}, 0.5 \mathrm{~min}$ of annealing at $63^{\circ} \mathrm{C}$, and 45 seconds of extension at $72^{\circ} \mathrm{C}$. The PCR products were digested at $37^{\circ} \mathrm{C}$ for $3 \mathrm{~h}$ with $10 \mathrm{U}$ of Hin-1 (NlaIII) endonuclease (Fermentase Canada). The fragments were separated by electrophoresis on a $1.5 \%$ agarose gel. "T" allele was in two fragments of 215 and $70 \mathrm{bp}$, while the uncut "C" allele had $285 \mathrm{bp}$.

\section{Statistical Analysis}

Qualitative variables were presented as raw count and percentage. Mean \pm standard deviation was used for the presentation of quantitative variables. Because of the non-normal distribution of the data statistical analysis were done using the non-parametric Kruskal-Wallis
One-Way Analysis of Variance and post hoc analysis was performed by the Dunn procedure for pair wise comparison. Allele frequency was computed with the Powermaker program [42]. A P-value of less than 0.05 was considered statistically significant.

\section{Results}

We investigated the frequency and phenotypic associations of the Taq1B and $-514 \mathrm{C} / \mathrm{T}$ polymorphisms in CETP and LIPC genes respectively in 252 (55.4\%) women and $203(44.6 \%)$ men with the mean age of $55.8 \pm 11.2$. Table 1 summarizes the demographic and biochemical characteristics of all the subjects as well as in each sex group separately. Women had significantly higher levels of BMI, TC, HDL-C, LDL-C and MDA than men $(p=0.001)$. TG was similar in both sexes.

\section{CETP Taq1B polymorphism frequency and its relation with the serum lipids}

As demonstrated in Table 2, heterozygote subjects with $51.0 \%$ frequency were the most common genotype, followed by B1B1 (28.4\%) and B2B2 (20.6\%) variants. This prevalence was similar in both sexes (data not shown).

B2 homozygote subjects had significantly higher means of serum total cholesterol than B1B1 genotype. Statistically significant difference was also found in the serum HDL-C levels among different genotypes of Taq1B polymorphisms with the highest level noted in $\mathrm{B} 2 \mathrm{~B} 2$ subjects followed by B1B2 and B1B1 $(P=0.01)$. Polymorphism at this locus, however, had no association with the LDL-C and TG levels in all the participants. Only in male subjects, however, LDL-C level was significantly higher in B2B2 subjects than B1B1 genotype (132 vs. $111 \mathrm{mg} / \mathrm{dl}, P=0.011)$. Serum TG level was also higher in B2B2 male subjects than B1B2 (214 vs. 186 $\mathrm{mg} / \mathrm{dl}, P=0.041$ ) (Data not shown). MDA, as a marker for lipid peroxidation, was not significantly different between the three genotypes.

Table 3 shows the comparison between the carriers for each "B1" and "B2" alleles with non carriers. "B1" carriers, had lower levels of TC, HDL-C and MDA ( $P=$ $0.005,0.009$ and 0.031 , respectively) than non carriers. The means for all the serum lipids, including the HDLC, were higher in "B2" allele carriers than non carriers but this difference was not statistically significant.

\section{LIPC polymorphism frequency and its association with serum lipids}

The most common form of the $-514 \mathrm{C} / \mathrm{T}$ polymorphism in LIPC gene was CC with $74.4 \%$ prevalence followed by $\mathrm{CT}$ and then TT genotype that was found only in 11 subjects (Table 4). In all the subjects no significant differences were found in TC, LDL-C, TG and MDA 
Table 1 Demographic and biochemical characteristics for all study participants and according to sex

\begin{tabular}{|c|c|c|c|c|}
\hline Variable & $\begin{array}{c}\text { All } \\
(n=455)\end{array}$ & $\begin{array}{c}\text { Male } \\
(n=203)\end{array}$ & $\begin{array}{c}\text { Female } \\
(\mathrm{n}=252)\end{array}$ & $P$ Value \\
\hline Percent & 100 & 44.6 & 55.4 & \\
\hline Age(year) & $55.8 \pm 11.2^{*}$ & $58.0 \pm 11.7$ & $54.0 \pm 10.4$ & 0.001 \\
\hline BMI, $\left(\mathrm{Kg} / \mathrm{m}^{2}\right)$ & $28.0 \pm 4.7$ & $26.1 \pm 3.6$ & $29.5 \pm 5.0$ & 0.001 \\
\hline $\mathrm{TC},(\mathrm{mg} / \mathrm{dl})$ & $203.2 \pm 40.5$ & $192.8 \pm 37.2$ & $211.5 \pm 41.2$ & 0.001 \\
\hline $\mathrm{HDL},(\mathrm{mg} / \mathrm{dl})$ & $36.2 \pm 8.8$ & $33.3 \pm 8.0$ & $38.6 \pm 8.7$ & 0.001 \\
\hline LDL, (mg/dl) & $128.4 \pm 32.9$ & $121.2 \pm 30.8$ & $134.3 \pm 33.5$ & 0.001 \\
\hline TG, (mg/dl) & $200.0 \pm 112.6$ & $197.0 \pm 115.2$ & $202.5 \pm 110.5$ & 0.599 \\
\hline Malondialdehyde, $(\mathrm{nmol} / \mathrm{mL})$ & $4.6 \pm 1.8$ & $4.2 \pm 1.9$ & $4.8 \pm 1.8$ & 0.001 \\
\hline
\end{tabular}

*Values are expressed as mean \pm SD

serum levels between the 3 genotypes of the LIPC polymorphism. The highest level of HDL-C was found in TT genotype followed by $\mathrm{CT}$ and then $\mathrm{CC}(\mathrm{TT}>\mathrm{CT}>$ $\mathrm{CC}$ ). But this difference was significant only in female participants between the heterozygote subjects and " $\mathrm{C}$ " homozygotes ( $41 \mathrm{vs} .38 \mathrm{mg} / \mathrm{dl}, P=0.021$ ). (Data not shown)

To assess the effect of the " $\mathrm{T}$ " allele on serum lipid levels, 117 carriers of this allele were compared with 338 non-carriers (CC genotype) (Table 5$)$. This analysis showed higher HDL-C level in " $\mathrm{T}$ " carriers than $\mathrm{CC}$ subjects (37.7 vs. $35.7 \mathrm{mg} / \mathrm{dl}, P=0.047)$. No other association was found for " $\mathrm{T}$ " or " $\mathrm{C}$ " allele carriers.

\section{Discussion}

To explore the potential genetic aspects of the high prevalence of low HDL-C levels in the populations of Tehran, we compared the serum lipids in different genotypes of the CETP Taq1B and LIPC polymorphisms in 455 residents of Tehran. The frequency of the CETP "B2" allele in this study was $46.1 \%$ which is higher than the $38.21 \%$ previously found by Daneshpour et al.[43] in a group of Tehran's residents. However, it is in accordance with the prevalence of $42 \%$ that was reported in White and East Asian populations[44]. In comparison to B1B1 genotype, B2 hetero and homozygote subjects had respectively $2.26 \%$ and $7.36 \%$ higher levels of HDL-C. This positive role is in agreement with the results of the two other studies carried in Iran $[43,45]$. Thompson et al. in their meta- analysis study, that covers the results of 92 studies in different ethnic groups with more than 113,000 subjects, have also found a $4.5 \%$ increase in HDL-C levels and a $0.9 \%$ and $2 \%$ decrease in LDL-C and TG levels respectively for each inherited B2 allele [44]. But, similar to Daneshpour et al[43], in the whole population of our participants we did not find any significant difference in the serum levels of LDL-C and TG between different genotypes of CETP Taq1B polymorphism.

In comparison to B2B2 subjects, lower means of $\mathrm{TC}$ and HDL-C in "B1" allele carriers by $7.5 \%$ and $5.8 \%$ respectively, shows the negative role of "B1" allele on the TC and HDL-C level.

The frequency of " $\mathrm{T}$ " allele in this study group was $14.0 \%$ and only 11 subjects (6 men and 5 women) were found with TT genotype. No comparable data was available for the prevalence of LIPC gene polymorphism in Iran. However, in comparison to the prevalence of " $\mathrm{T}$ " allele in 20 other studies in different ethnic groups, summarized by Isaac et al.[17], the frequency of " $T$ " allele in our participants was the lowest, in particular as compared with that of East Asian population. However,

Table 2 Biochemical variables according to CETP polymorphism

\begin{tabular}{|c|c|c|c|c|}
\hline \multirow[b]{2}{*}{ Variable } & \multicolumn{4}{|c|}{ CETP Polymorphism } \\
\hline & $\begin{array}{c}\text { B2B2 } \\
(n=94)\end{array}$ & $\begin{array}{c}\text { B1B2 } \\
(n=232)\end{array}$ & $\begin{array}{c}\text { B1B1 } \\
(n=129)\end{array}$ & $P$ value \\
\hline Prevalence, (\%) & 20.6 & 51.0 & 28.4 & \\
\hline Total cholesterol, (mg/dl) & $215.2 \pm 44.1^{*} \dagger$ & $202.2 \pm 39.0$ & $196.6 \pm 39.3$ & 0.011 \\
\hline HDL cholesterol, (mg/dl) & $37.9 \pm 7.4 \neq$ & $36.1 \pm 9.0$ & $35.3 \pm 9.6$ & 0.017 \\
\hline LDL cholesterol, (mg/dl) & $135.7 \pm 33.2$ & $128.2 \pm 32.0$ & $123.3 \pm 33.5$ & 0.088 \\
\hline Triglyceride, (mg/dl) & $209.2 \pm 123.6$ & $201.3 \pm 115.0$ & $191.0 \pm 99.5$ & 0.227 \\
\hline Malondialdehyde, (nmol/mL) & $5.0 \pm 2.1$ & $4.5 \pm 1.7$ & $4.4 \pm 1.8$ & 0.084 \\
\hline
\end{tabular}

*Values are expressed as mean \pm SD

† Shows significant difference between B2B2 and B1

¥Shows significant difference between B2B2 genotype with both B1B2 and B1B1 
Table 3 Comparison of biochemical variables in CETP "B1" and "B2" allele carriers with non carriers

\begin{tabular}{lcccccc}
\hline & \multicolumn{3}{c}{ “B1" Allele } & \multicolumn{3}{c}{ "B2" Allele } \\
\cline { 2 - 7 } Variable & B1 (+) & B1 (-) & P Value & B2 (+) & B2 (-) & P Value \\
\hline Number & 361 & 94 & & 326 & 129 \\
Total cholesterol, (mg/dl) & $200.1 \pm 39.0^{*}$ & $215.2 \pm 44.1$ & 0.005 & $205.8 \pm 40.8$ & $196.6 \pm 39.3$ & 0.054 \\
HDL cholesterol, (mg/dl) & $35.8 \pm 9.1$ & $37.9 \pm 1.4$ & 0.009 & $36.6 \pm 8.4$ & $35.3 \pm 9.6$ & 0.055 \\
LDL cholesterol, (mg/dl) & $126.4 \pm 32.6$ & $135.7 \pm 33.2$ & 0.051 & $130.4 \pm 32.5$ & $123.3 \pm 33.5$ & 0.107 \\
Triglyceride, (mg/dl) & $197.6 \pm 109.6$ & $209.2 \pm 123.6$ & 0.258 & $203.6 \pm 117.3$ & $191.0 \pm 99.5$ & 0.510 \\
Malondialdehyde, (nmol/mL) & $4.5 \pm 1.1$ & $5.0 \pm 2.1$ & 0.031 & $4.6 \pm 1.9$ & $4.4 \pm 1.8$ & 0.224 \\
\hline
\end{tabular}

*Values are expressed as mean \pm SD

further studies with larger sample sizes are needed to confirm this finding. Although not statistically significant, the approximately $15.2 \%$ lower level of HDL-C in "C" carriers than non carriers is a notable difference. Besides, HDL-C level was 5.3\% higher in 117 carriers of " $\mathrm{T}$ " allele than 338 non carriers. This is in agreement with the common findings of the other studies relating " $\mathrm{T}$ " allele to higher HDL-C level and lower enzyme activity $[11,17,21,46]$.

Considering the protective action of HDL-C against LDL-C peroxidation [47] and the roles of CETP and HL enzymes in the metabolism of HDL-C, MDA - as a presumptive marker of oxidant-mediated lipid peroxidation - was compared among different genotypes. However, lack of any association between MDA level and genetic polymorphisms might be justified by the need to a more sensitive and direct method for the measurement of lipid peroxidation.

The major limitations of this study includes its cross sectional nature, an absence of data regarding the habitual dietary intake and physical activity of the subjects, no measurement of the CETP and HL enzymes activity and the sample size.

In summary, our study demonstrated a significant association between Taq1B polymorphism in CETP gene and HDL-C variability with the highest HDL-C levels found in "B2" homozygotes. "B1" allele of CETP was also related to the lower levels of HDL-C. Conversely, higher means of HDL-C was found in the " $\mathrm{T}$ " allele carriers of $-514 \mathrm{C} / \mathrm{T}$ polymorphism in LIPC gene. MDA level was not associated with these two polymorphisms. However, studies with larger sample sizes are needed to confirm these findings.

Table 4 Biochemical variables according to LIPC polymorphisms

\begin{tabular}{lcccc}
\hline & \multicolumn{4}{c}{ LIPC Polymorphism } \\
\cline { 2 - 5 } Variable & $\begin{array}{c}\boldsymbol{T} \\
(\mathbf{n}=\mathbf{1 1})\end{array}$ & $\begin{array}{c}\mathbf{C T} \\
\mathbf{( n = 1 0 6})\end{array}$ & $\begin{array}{c}\text { CC } \\
(\mathbf{n}=\mathbf{3 3 8})\end{array}$ \\
\hline Prevalence, (\%) & 2.4 & 23.2 & 74.4 & $\boldsymbol{P}$ value \\
Total cholesterol, (mg/dl) & $218.0 \pm 48.0^{*}$ & $205.0 \pm 43.0$ & $202.0 \pm 40.0$ & 0.150 \\
HDL cholesterol, (mg/d) & $42.0 \pm 11.0$ & $37.0 \pm 10.0$ & $36.0 \pm 8.0$ & 0.062 \\
LDL cholesterol, (mg/dl) & $135.0 \pm 42.0$ & $127.0 \pm 36.0$ & $129.0 \pm 32.0$ & 0.413 \\
Triglyceride, $(\mathbf{m g} / \mathbf{d l})$ & $225.0 \pm 102.0$ & $211.0 \pm 123.0$ & $196.0 \pm 109.0$ & 0.290 \\
Malondialdehyde, $(\mathbf{n m o l} / \mathbf{m L})$ & $5.2 \pm 1.6$ & $4.7 \pm 2.0$ & $4.5 \pm 1.8$ & 0.312 \\
\hline
\end{tabular}

*Values are expressed as mean \pm SD

Table 5 Comparison of biochemical variables in LIPC " $\mathrm{C}$ " and " $\mathrm{T}$ " allele carriers with non carriers

\begin{tabular}{|c|c|c|c|c|c|c|}
\hline \multirow[b]{2}{*}{ Variable } & \multicolumn{3}{|c|}{ "C" Allele } & \multicolumn{3}{|c|}{ "T" Allele } \\
\hline & $\underset{(+)}{C}$ & $\begin{array}{c}C \\
(-)\end{array}$ & $P$ Value & $\begin{array}{c}\mathrm{T} \\
(+)\end{array}$ & $\begin{array}{c}T \\
(-)\end{array}$ & $P$ Value \\
\hline Number & 444 & 11 & & 117 & 338 & \\
\hline Total cholesterol, (mg/dl) & $202.8 \pm 40.3^{*}$ & $217.9 \pm 47.9$ & 0.093 & $206.6 \pm 43.3$ & $202.0 \pm 39.5$ & 0.163 \\
\hline HDL cholesterol, (mg/dl) & $36.1 \pm 8.7$ & $41.6 \pm 11.3$ & 0.080 & $37.7 \pm 10.1$ & $35.7 \pm 8.2$ & 0.047 \\
\hline LDL cholesterol, (mg/dl) & $128.2 \pm 32.7$ & $134.7 \pm 42.2$ & 0.206 & $127.6 \pm 36.5$ & $128.6 \pm 31.7$ & 0.956 \\
\hline Triglyceride, (mg/dl) & $199.4 \pm 112.9$ & $225.0 \pm 102.1$ & 0.281 & $212.6 \pm 120.9$ & $195.6 \pm 109.4$ & 0.231 \\
\hline Malondialdehyde, (nmol/mL) & $4.6 \pm 1.9$ & $5.2 \pm 1.6$ & 0.137 & $4.7 \pm 2.5$ & $4.5 \pm 1.8$ & 0.454 \\
\hline
\end{tabular}

*Values are expressed as mean \pm SD 


\section{Acknowledgements}

We are grateful to all the volunteers who kindly took part in our research. Hereby we are also thankful for the scientific and technical supports from: M. Jalali, P. Mehdi Poor, J. Ghanbili, M. Ahmadi, R. Russel, M. Meydani and J. Ordovas. This work was supported by Tehran University of Medical Sciences under grant No: 3585-27-02-85 and Endocrine Research Center fund No: 41481

\section{Author details}

'Department of Nutrition and Biochemistry, School of Public Health, Tehran University of Medical Sciences, Tehran, I.R.Iran. ${ }^{2}$ Endocrine Research Center, Research Institute for Endocrine Sciences, Shahid Beheshti University of Medical Sciences, Tehran, I.R. Iran. ${ }^{3}$ Obesity Research Center, Research Institute for endocrine sciences, Shaheed Beheshti University of Medical Sciences, Tehran, I.R. Iran. ${ }^{4}$ Department of Epidemiology and Biostatistics, School of Public Health, Tehran University of Medical Sciences, Tehran, I.R. Iran.

\section{Authors' contributions}

MAKF conceived of the study and performed its design, laboratory measurements and statistical analysis, interpreted the results and the prepared the draft of the manuscript. AF has established the TLG study and cooperated in all the steps of this project, especially its design and the draft of the manuscript. MH has collaborated vigorously in the biochemical measurements. MSD has strongly helped in the genetic analysis. ARS has participated in the statistical analysis. FS, as the corresponding author, has supervised all the steps of the project and collaborated in the interpretation of the results and the preparation of the draft of the manuscript. All authors read and approved the final manuscript.

\section{Competing interests}

The authors declare that they have no competing interests.

Received: 21 July 2010 Accepted: 7 September 2010

Published: 7 September 2010

\section{References}

1. Mackay J, Mensah GA: The Atlas of Heart Disease and Stroke (World Health Organization, Geneva). 2004.

2. Kuulasmaa K, Tunstall-Pedoe H, Dobson A, Fortmann S, Sans S, Tolonen H, Evans A, Ferrario M, Tuomilehto J: Estimation of contribution of changes in classic risk factors to trends in coronary-event rates across the WHO MONICA Project populations. Lancet 2000, 355:675-687.

3. Clarke R, Emberson JR, Parish S, Palmer A, Shipley M, Linksted P, Sherliker P, Clark S, Armitage J, Fletcher A, Collins R: Cholesterol fractions and apolipoproteins as risk factors for heart disease mortality in older men. Arch Intern Med 2007, 167:1373-1378.

4. Chapman MJ, Assmann G, Fruchart JC, Shepherd J, Sirtori C: Raising highdensity lipoprotein cholesterol with reduction of cardiovascular risk: the role of nicotinic acid-a position paper developed by the European Consensus Panel on HDL-C. Curr Med Res Opin 2004, 20:1253-1268.

5. Chapman MJAG, Fruchart JC, Shepherd J, Sirtori C: Raising high-density lipoprotein cholesterol with reduction of cardiovascular risk: the role of nicotinic acid-a position paper developed by the European Consensus Panel on HDL-C. Curr Med Res Opin 2004, 20(8):1253-1268.

6. Gordon DJRB: High-density lipoprotein-the clinical implications of recent studies. N Engl J Med 1989, 321(19):1311-1316

7. Kraus WE, Houmard JA, Duscha BD, Knetzger KJ, Wharton MB, McCartney JS, Bales CW, Henes S, Samsa GP, Otvos JD, et al: Effects of the amount and intensity of exercise on plasma lipoproteins. $N$ Engl I Med 2002, 347:1483-1492.

8. Pilia G, Chen WM, Scuteri A, Orru M, Albai G, Dei M, Lai S, Usala G, Lai M, Loi $P$, et al: Heritability of cardiovascular and personality traits in 6,148 Sardinians. PLoS Genet 2006, 2:e132

9. Willer CJ, Sanna S, Jackson AU, Scuteri A, Bonnycastle LL, Clarke R, Heath SC, Timpson NJ, Najjar SS, Stringham HM, et al: Newly identified loci that influence lipid concentrations and risk of coronary artery disease. Nat Genet 2008, 40:161-169.

10. Kathiresan S, Melander O, Guiducci C, Surti A, Burtt NP, Rieder MJ, Cooper GM, Roos C, Voight BF, Havulinna AS, et al: Six new loci associated with blood low-density lipoprotein cholesterol, high-density lipoprotein cholesterol or triglycerides in humans. Nat Genet 2008, 40:189-197.

11. Guerra R, Wang J, Grundy SM, Cohen JC: A hepatic lipase (LIPC) allele associated with high plasma concentrations of high density lipoprotein cholesterol. Proc Natl Acad Sci USA 1997, 94:4532-4537.

12. Cohen JC, Wang Z, Grundy SM, Stoesz MR, Guerra R: Variation at the hepatic lipase and apolipoprotein AI/CIII/AIV loci is a major cause of genetically determined variation in plasma HDL cholesterol levels. J Clin Invest 1994, 94:2377-2384.

13. Tall AR: Plasma cholesteryl ester transfer protein. J Lipid Res 1993, 34:1255-1274.

14. Barter PJ, Brewer HB, Chapman MJ, Hennekens CH, Rader DJ, Tall AR: Cholesteryl ester transfer protein: a novel target for raising HDL and inhibiting atherosclerosis. Arterioscler Thromb Vasc Biol 2003, 23:160-167.

15. Drayna D, Lawn R: Multiple RFLPs at the human cholesteryl ester transfer protein (CETP) locus. Nucleic Acids Res 1987, 15:4698.

16. Hannuksela ML, Liinamaa MJ, Kesaniemi YA, Savolainen MJ: Relation of polymorphisms in the cholesteryl ester transfer protein gene to transfer protein activity and plasma lipoprotein levels in alcohol drinkers. Atherosclerosis 1994, 110:35-44.

17. Isaacs A, Sayed-Tabatabaei FA, Njajou OT, Witteman JC, van Duijn CM: The -514 C- > T hepatic lipase promoter region polymorphism and plasma lipids: a meta-analysis. J Clin Endocrinol Metab 2004, 89:3858-3863.

18. Juo SH, Han Z, Smith JD, Colangelo L, Liu K: Promoter polymorphisms of hepatic lipase gene influence $\mathrm{HDL}(2)$ but not $\mathrm{HDL}(3)$ in African American men: CARDIA study. J Lipid Res 2001, 42:258-264.

19. Johnson WJ, Bamberger MJ, Latta RA, Rapp PE, Phillips MC, Rothblat GH: The bidirectional flux of cholesterol between cells and lipoproteins Effects of phospholipid depletion of high density lipoprotein. I Biol Chem 1986, 261:5766-5776

20. Kadowaki H, Patton GM, Robins SJ: Metabolism of high density lipoprotein lipids by the rat liver: evidence for participation of hepatic lipase in the uptake of cholesteryl ester. J Lipid Res 1992, 33:1689-1698.

21. Jansen H, Chu G, Ehnholm C, Dallongeville J, Nicaud V, Talmud PJ: The T allele of the hepatic lipase promoter variant C-480T is associated with increased fasting lipids and HDL and increased preprandial and postprandial LpCIII: B: European Atherosclerosis Research Study (EARS) II. Arterioscler Thromb Vasc Biol 1999, 19:303-308.

22. Jansen H, Verhoeven AJ, Weeks L, Kastelein JJ, Halley DJ, van den Ouweland A, Jukema JW, Seidell JC, Birkenhager JC: Common C-to-T substitution at position -480 of the hepatic lipase promoter associated with a lowered lipase activity in coronary artery disease patients. Arterioscler Thromb Vasc Biol 1997, 17:2837-2842.

23. Couture P, Otvos JD, Cupples LA, Lahoz C, Wilson PW, Schaefer EJ, Ordovas JM: Association of the C-514T polymorphism in the hepatic lipase gene with variations in lipoprotein subclass profiles: The Framingham Offspring Study. Arterioscler Thromb Vasc Biol 2000, 20:815-822.

24. Ordovas JM, Corella D, Demissie S, Cupples LA, Couture P, Coltell O, Wilson PW, Schaefer EJ, Tucker KL: Dietary fat intake determines the effect of a common polymorphism in the hepatic lipase gene promoter on high-density lipoprotein metabolism: evidence of a strong dose effect in this gene-nutrient interaction in the Framingham Study. Circulation 2002, 106:2315-2321.

25. Ko YL, Hsu LA, Hsu KH, Ko YH, Lee YS: The interactive effects of hepatic lipase gene promoter polymorphisms with sex and obesity on highdensity-lipoprotein cholesterol levels in Taiwanese-Chinese. Atherosclerosis 2004, 172:135-142.

26. Tahvanainen E, Syvanne M, Frick MH, Murtomaki-Repo S, Antikainen M, Kesaniemi YA, Kauma H, Pasternak A, Taskinen MR, Ehnholm C: Association of variation in hepatic lipase activity with promoter variation in the hepatic lipase gene. The LOCAT Study Invsestigators. J Clin Invest 1998, 101:956-960.

27. Carr MC, Ayyobi AF, Murdoch SJ, Deeb SS, Brunzell JD: Contribution of hepatic lipase, lipoprotein lipase, and cholesteryl ester transfer protein to LDL and HDL heterogeneity in healthy women. Arterioscler Thromb Vasc Biol 2002, 22:667-673.

28. Fang DZ, Liu BW: Polymorphism of $\mathrm{HL}+1075 \mathrm{C}$, but not $-480 \mathrm{~T}$, is associated with plasma high density lipoprotein cholesterol and apolipoprotein Al in men of a Chinese population. Atherosclerosis 2002, $161: 417-424$ 
29. St-Pierre J, Miller-Felix I, Paradis ME, Bergeron J, Lamarche B, Despres JP, Gaudet D, Vohl MC: Visceral obesity attenuates the effect of the hepatic lipase $-514 C>$ T polymorphism on plasma HDL-cholesterol levels in French-Canadian men. Mol Genet Metab 2003, 78:31-36.

30. Azizi F, Rahmani M, Emami H, Mirmiran P, Hajipour R, Madjid M, Ghanbili J, Ghanbarian A, Mehrabi Y, Saadat N, et al: Cardiovascular risk factors in an Iranian urban population: Tehran lipid and glucose study (phase 1). Soz Praventivmed 2002, 47:408-426.

31. Ghassemi H, Harrison G, Mohammad K: An accelerated nutrition transition in Iran. Public Health Nutr 2002, 5:149-155.

32. Sharrett AR, Ballantyne CM, Coady SA, Heiss G, Sorlie PD, Catellier D, Patsch W: Coronary heart disease prediction from lipoprotein cholesterol levels, triglycerides, lipoprotein(a), apolipoproteins A-I and B, and HDL density subfractions: The Atherosclerosis Risk in Communities (ARIC) Study. Circulation 2001, 104:1108-1113.

33. Castelli WP, Garrison RJ, Wilson PW, Abbott RD, Kalousdian S, Kannel WB: Incidence of coronary heart disease and lipoprotein cholesterol levels. The Framingham Study. JAMA 1986, 256:2835-2838.

34. Heiss G, Tamir I, Davis CE, Tyroler HA, Rifkand BM, Schonfeld G, Jacobs D, Frantz ID Jr: Lipoprotein-cholesterol distributions in selected North American populations: the lipid research clinics program prevalence study. Circulation 1980, 61:302-315.

35. Azizi F: Tehran Lipid and Glucose Study, study methodology and summarized findings. Endocrine Research Center Publication, Tehran 2001.

36. Fumeron F, Betoulle D, Luc G, Behague I, Ricard S, Poirier O, Jemaa R, Evans A, Arveiler D, Marques-Vidal P, et al: Alcohol intake modulates the effect of a polymorphism of the cholesteryl ester transfer protein gene on plasma high density lipoprotein and the risk of myocardial infarction. J Clin Invest 1995, 96:1664-1671.

37. Azizi F, Rahmani M, Emami H, Madjid M: Tehran Lipid and Glucose Study: rationale and design. CVD Prev 2000, 3:242-247.

38. Friedewald WT, Levy Rl, Fredrickson DS: Estimation of the concentration of low-density lipoprotein cholesterol in plasma, without use of the preparative ultracentrifuge. Clin Chem 1972, 18:499-502.

39. Wade $C R$, van Rij AM: Plasma thiobarbituric acid reactivity: reaction conditions and the role of iron, antioxidants and lipid peroxy radicals on the quantitation of plasma lipid peroxides. Life Sci 1988, 43:1085-1093.

40. Truett GE, Heeger $P$, Mynatt RL, Truett AA, Walker JA, Warman ML: Preparation of PCR-quality mouse genomic DNA with hot sodium hydroxide and tris (HotSHOT). Biotechniques 2000, 29:52-54.

41. Ordovas JM, Cupples LA, Corella D, Otvos JD, Osgood D, Martinez A, Lahoz C, Coltell O, Wilson PW, Schaefer EJ: Association of cholesteryl ester transfer protein-TaqIB polymorphism with variations in lipoprotein subclasses and coronary heart disease risk: the Framingham study. Arterioscler Thromb Vasc Biol 2000, 20:1323-1329.

42. Liu K, Muse SV: PowerMarker: an integrated analysis environment for genetic marker analysis. Bioinformatics 2005, 21:2128-2129.

43. Daneshpour MS, Hedayati M, Azizi F: Taql B1/B2 and -629A/C cholesteryl ester transfer protein (CETP) gene polymorphisms and their association with CETP activity and high-density lipoprotein cholesterol levels in a Tehranian population. Part of the Tehran Lipid and Glucose Study (TLGS). Genetics and Molecular Biology 2007, 30:1039-1046.

44. Thompson A, Di Angelantonio E, Sarwar N, Erqou S, Saleheen D, Dullaart RP, Keavney B, Ye Z, Danesh J: Association of cholesteryl ester transfer protein genotypes with CETP mass and activity, lipid levels, and coronary risk. JAMA 2008, 299:2777-2788.

45. Hassanzadeh T, Firoozrai M, Zonouz AE, Zavarehee A, Paoli M: Taq1B polymorphism of cholesteryl ester transfer protein (CETP) gene in primary combined hyperlipidaemia. Indian J Med Res 2009, 129:293-298.

46. van't Hooft FM, Lundahl B, Ragogna F, Karpe F, Olivecrona G, Hamsten A: Functional characterization of 4 polymorphisms in promoter region of hepatic lipase gene. Arterioscler Thromb Vasc Biol 2000, 20:1335-1339.

47. Aviram M, Rosenblat M: Paraoxonases and cardiovascular diseases: pharmacological and nutritional influences. Curr Opin Lipidol 2005, 16:393-399.

doi:10.1186/1476-511X-9-96

Cite this article as: Kashani Farid et al:: Association between CETP Taq1B and LIPC $-514 C / T$ polymorphisms with the serum lipid levels in a group of Tehran's population: a cross sectional study. Lipids in Health and Disease 2010 9:96.

\section{Submit your next manuscript to BioMed Central and take full advantage of:}

- Convenient online submission

- Thorough peer review

- No space constraints or color figure charges

- Immediate publication on acceptance

- Inclusion in PubMed, CAS, Scopus and Google Scholar

- Research which is freely available for redistribution 